\title{
Longitudinal profile and sediment mobility as geomorphic tools to interpret the history of a fluviokarst stream system
}

\author{
John Woodside ${ }^{1,2}$, Eric W. Peterson ${ }^{1 *}$, and Toby Dogwiler ${ }^{3,4}$ \\ ${ }^{1}$ Department of Geography-Geology, Illinois State University, Normal, IL 61790 \\ ${ }^{2}$ currently at Minnesota Department of Health, Minneapolis, MN 55401 \\ ${ }^{3}$ Southeastern Minnesota Water Resources Center, Department of Geoscience, Winona State University, Winona, MN 55987 \\ ${ }^{4}$ currently at Department of Geography, Geology, and Planning, Missouri State University, Springfield, MO 65897
}

\begin{abstract}
The complex drainage systems within karst settings can result in atypical longitudinal profiles. Features, such as cave entrances, can be expressed as anomalous 'bumps' in the longitudinal profile of a stream if downcutting has continued upstream of the area in which the water is pirated to the subsurface. Horn Hollow, a fluviokarst valley located in Carter Caves State Park Resort in northeastern Kentucky, was examined for these types of features. The objectives of this study were to determine if sediment mobility can be used as a proxy for anomalous areas along the profile of the valley and if detailed cross-sections can reveal and/ or differentiate areas of cave collapse from natural down-cutting of the system. To accomplish these objectives, the longitudinal profile of Horn Hollow and numerous cross-sections through the valley were surveyed. Armor point counts were performed at cross-sections unless the section was predominantly bedrock. Although Horn Hollow's waters have been predominantly pirated to the subsurface, the longitudinal profile of the system is graded to that of a stream near equilibrium, but anomalous areas are present. The progression of sediment size along the length of the profile does not follow a typical fining-downstream pattern. Some of the largest sediments can be found within the lower segment of the profile. Taken together, the anomalous bumps and the sediment size suggest that the shape of the longitudinal stream profile is strongly influenced by karst processes such as stream piracy and cave collapse.
\end{abstract}

Keywords: fluvial geomorphology; karst; stream profile; shear stress; sediment

Received 4 February 2014; Revised 23 March 2015; Accepted 1 April 2015

Citation: Woodside J., Peterson E.W. and Dogwiler T., 2015. Longitudinal profile and sediment mobility as geomorphic tools. International Journal of Speleology, 44 (2), 197-206. Tampa, FL (USA) ISSN 0392-6672 http://dx.doi.org/10.5038/1827-806X.44.2.9

\section{INTRODUCTION}

Karst terrains, characterized by closed depressions, subsurface drainage, and caves, account for approximately 10-20\% of Earth's land area (Palmer, 1991; Gillieson, 1996). The degree of karst development varies from region to region as a result of climatic conditions and relief. Consequently, a land surface may exhibit gently rolling soil covered plains with slight depressions or it may include deep depressions, isolated towers, and pointed hills (White, 1988).

Dissolution plays a more significant role in the development of karst landscapes than in other landscapes (Jennings, 1985). However, studies have shown that physical erosional processes may also play an important role in the formation of karst systems (Aley, 1965; Sanders, 1981; Palmer, 1991; Bosch \& White, 2004; Dogwiler \& Wicks, 2004). Regardless of the erosion process, the formation of karst in suitable rock types requires the movement of water, with the local relief being the driving force for the water movement (Jennings, 1985). Over time, water draining the basin may transition from a surface-dominated drainage to a subsurfacedominated drainage. As a result, rather than having an integrated fluvial network with small headwater streams in the headlands draining to higher order streams, karst drainage basins may contain tributary streams that end abruptly in swallets, and large streams that emerge at karst springs with no surface tributaries (Leopold et al., 1964; White, 1988).

The degree to which sediment serves as an abrasive agent is dependent on the mobility of the sediments (White \& White, 1968; Sklar \& Dietrich, 2001; Dogwiler \& Wicks, 2004). Past studies suggest that karst streams are armored with relatively immobile substrates (White \& White, 1968). However, work by Dogwiler \& Wicks (2004) and Van Gundy \& White (2009) in fluviokarst systems indicate that surficial and subterranean karst stream substrates are 
mobile during bankfull discharge conditions and can be predicted by standard shear stress analysis approaches (Baker \& Ritter, 1975; Lorang \& Hauer, 2003; Herman et al., 2012). Within the fluviokarst system of Devils Ice Box in Boone County, Missouri, Dogwiler \& Wicks (2004) observed that stream flows capable of entraining $d_{50}$ and $d_{85}$ particles occur at intervals of 2.4 and 11.7 months, respectively. The frequent particle impact and abrasion by bedload contributes to the loosening and removal of bedrock and creation of greater surface area on the sediment, increasing the rate of incision by mechanical and chemical processes within the karst system (Whipple et al., 2000). During baseflow, the sediment substrate overlying many active karst streams may hinder dissolution, leaving mechanical weathering as the dominant stream-shaping process.

Incision processes are dominant in the upper reaches and depositional processes dominate the lower reaches of a stream; thus, under normal conditions, the profile will be the most gentle near the mouth and steepest near its watershed divide (Leopold et al., 1964). In karst regions, stream profiles may have similar characteristics as profiles for non-karst streams, but due to the nature of the rocks (i.e. carbonates), water and sediments may be diverted from the surface into the subsurface, stream piracy. By altering changing the water pathways and subsequently, the processes of incision and deposition, the surface stream profile may evolve such that some reaches, downstream from where water is lost to subsurface pirating, experience little flow and much slower rates of incision.

In karst regions, a profile in equilibrium may contain a concave-downward segment as streambed piracy becomes more complete and better integrated with the subsurface drainage system (Fig. 1). By rerouting water underground, the surface expression of the stream may not change in the downstream reach as the absence of water results in no incision. However, upstream from the water sink (swallet) and downstream from the water resurgence, sediments will continue to be transported or deposited, causing the reaches upstream of the swallet and downstream of the resurgence to incise. The concave-downward profile becomes more pronounced as surface-stream incision becomes less effective and shorter-lived during heavy rainfall events (George, 1989). The presence of concave-downward segments along the stream profile may indicate the position of shafts

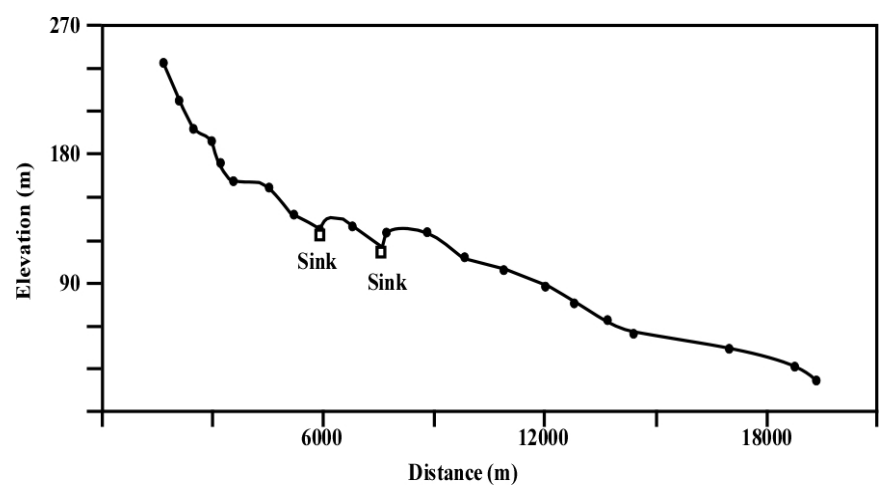

Fig. 1. General depiction of a longitudinal profile in a karst setting, displaying concave-down segments (modified from George, 1989). or other underground entrances within the stream channel. The lack of concave-downward sections may suggest that the system lacks a connection to subsurface drainage and represents a surface (non karst) system in equilibrium (George, 1989).

The objectives of this study were (1) to determine if a detailed longitudinal profile would reveal anomalous segments, ones that do not exhibit characteristics of fluvial systems or show karst window features, along the course of a karst stream and (2) to assess if sediment mobility can be used as a proxy for these anomalous segments. Quantitative and qualitative analyses of the relationship between the longitudinal profile, geomorphology, sediment characteristics, and known karst features along the course of the studied valley were used to elucidate the geomorphic history of the valley.

\section{LOCATION}

Field work was conducted in the Horn Hollow karst system, at Carter Caves State Resort Park (CCSRP) in northeastern Kentucky (Fig. 2). The study area is located within the northwest-central portion of Carter County, Kentucky. Typical to the geologic region, Carter County has numerous deeply-incised valleys, with elevations ranging from $345 \mathrm{~m}$ at the highest point to about $100 \mathrm{~m}$ at base-level. Approximately onequarter of Carter County consists of karst landscapes and there are over 200 named pits and caves within a $40 \mathrm{~km}$ radius of CCSRP (McGrain, 1966; Engel \& Engel, 2009; Jacoby et al., 2011a; Jacoby et al., 2011b; Peterson et al., 2011; Jacoby et al., 2013; Angel \& Peterson, 2015). The bedrock units in the study area are Mississippian and Pennsylvanian in age. A sequence of carbonates with a maximum thickness of about $25 \mathrm{~m}$ are bounded stratigraphically by siliciclastic units (Engel \& Engel, 2009). The bedrock in the area is on the west limb of the Waverly Arch and dips slightly $\left(>2^{\circ}\right)$ to the east-southeast (Rice et al., 1980). Eastern Kentucky is part of the tectonically quiescent North American craton. Karst development in the region is often controlled by subtle localized variations in dip of the relatively horizontal bedding (Palmer, 1989). Readers are directed to Engel \& Engel (2009) and Ochsenbein (1974) for detailed descriptions of the stratigraphy, regional structure, and topography of CCSRP.

The Horn Hollow karst system is a fluvial karst system consisting of the surface and subsurface drainage system associated with Horn Hollow Creek (Dogwiler \& Wicks, 2004; Angel \& Peterson, 2015). The system is a hidden valley perched 14 meters above Cave Branch, the main surface water stream within the park (McGrain, 1966). Horn Hollow Creek is ultimately a tributary of the Ohio River, via Cave Branch and Tygert's Creek.

At several points along its longitudinal profile Horn Hollow Creek is diverted into the subsurface and then resurges downstream (Fig. 3). Upstream of Bowel Spring, stream flow is intermittent. Dye tracing has shown that Boundary Cave drains to Bowel Spring and is fed by vadose infeeders located in some of the small upstream tributary valleys (Angel \& Peterson, 2015). A published 


\section{Horn Hollow Valley \\ Carter Caves State Resort Park}

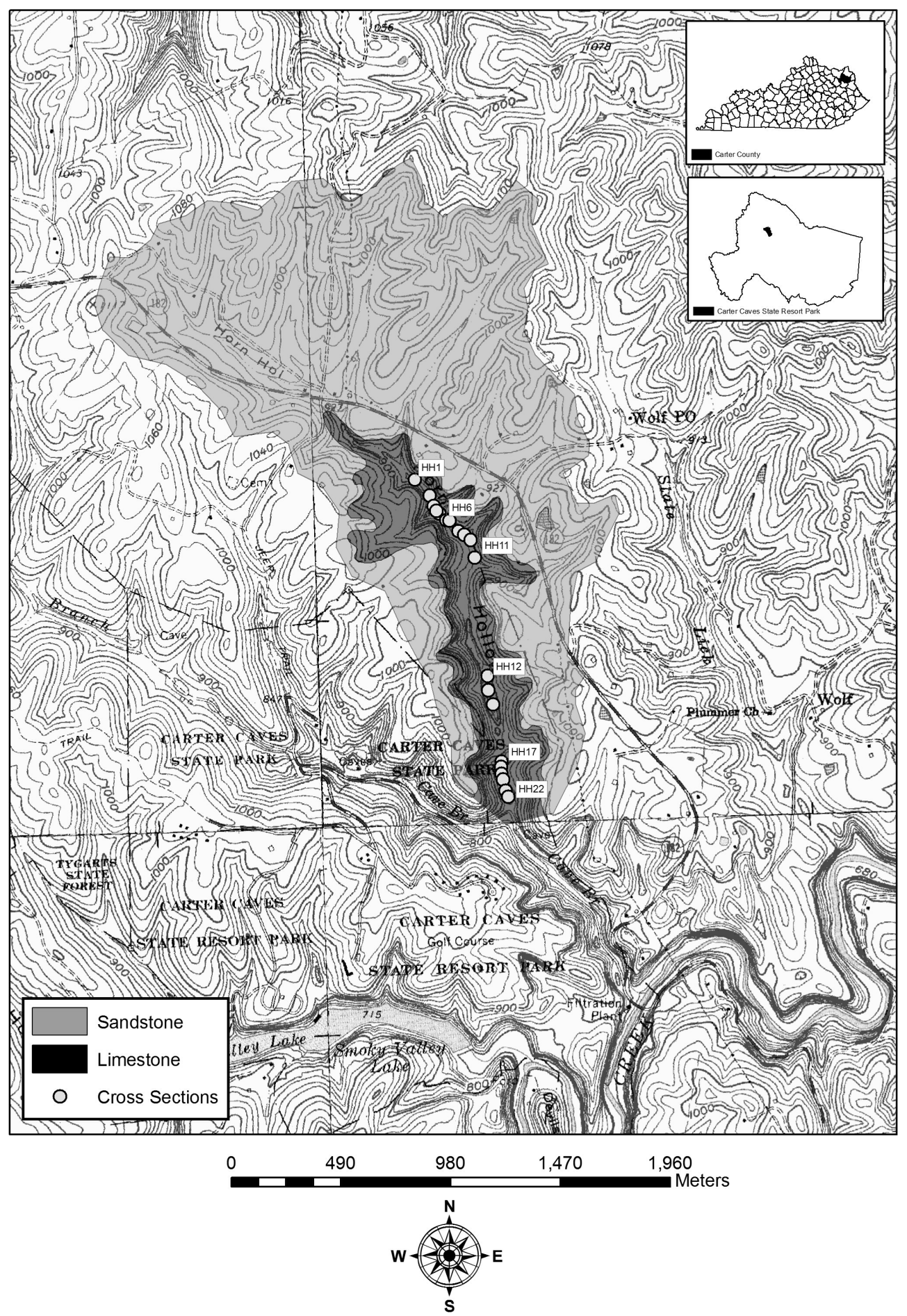

Fig. 2. Location and topography of Horn Hollow Valley at Carter Caves State Resort Park.

map is not available for Boundary Cave, but its main entrance (Fig. 3) is located in a bedrock outcropping within the intermittent stream channel. The subsurface path of Boundary Cave appears to coincide with the intermittent stream, at least in the reach associated with the cave entrance. Downstream from Bowel Spring, Horn Hollow Creek flows perennially.

A couple of hundred meters downstream of Bowel Spring the stream flows into the upstream entrance of Cobble Cave, which is essentially a subsurface meander bend under the eastern valley wall. Cobble Cave is a simple stream cave that can be fully traversed from its upstream end to its downstream resurgence. A dry stream reach with a well-defined surface channel connects the upstream and downstream entrances of Cobble Cave and serves as an overflow path for higher discharges.

From the resurgence of Cobble Cave, Horn Hollow Creek flows to the upstream entrance of Horn Hollow Cave. There is no surface overflow route around Horn Hollow Cave (Fig. 4); thus, during large discharge events water backs up in the valley between Cobble and Horn Hollow Caves. The stream follows a short, traversable path through Horn Hollow Creek and then sinks into the streambed immediately after emerging to the surface at the downstream end of the cave. The dry surface channel between Horn Hollow Cave and 


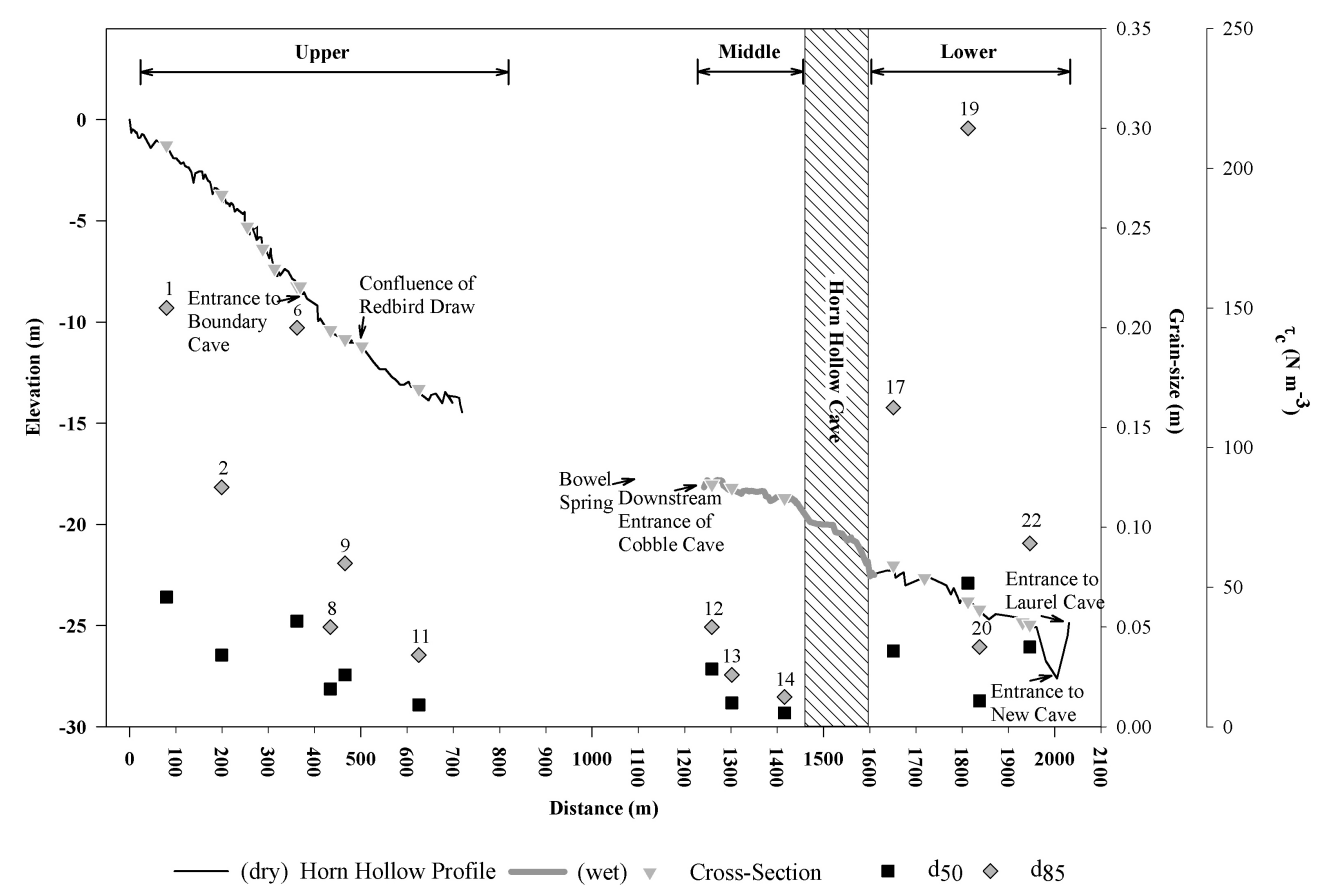

Fig. 3. Longitudinal profile of Horn Hollow Creek. Each triangle represents a survey location. Grain-size and critical shear stress values, represented by the same symbol, are provided for $d_{50}$ (black square) and $\mathrm{d}_{85}$ (gray diamond) at cross-sections with sediment along Horn Hollow Creek. Numbers indicate the respective cross-section. Since critical shear stress is a function of grain size, $\tau_{c 50}$ and $\tau_{c 85}$ plot directly on top of $d_{50}$ and $d_{85}$, respectively.

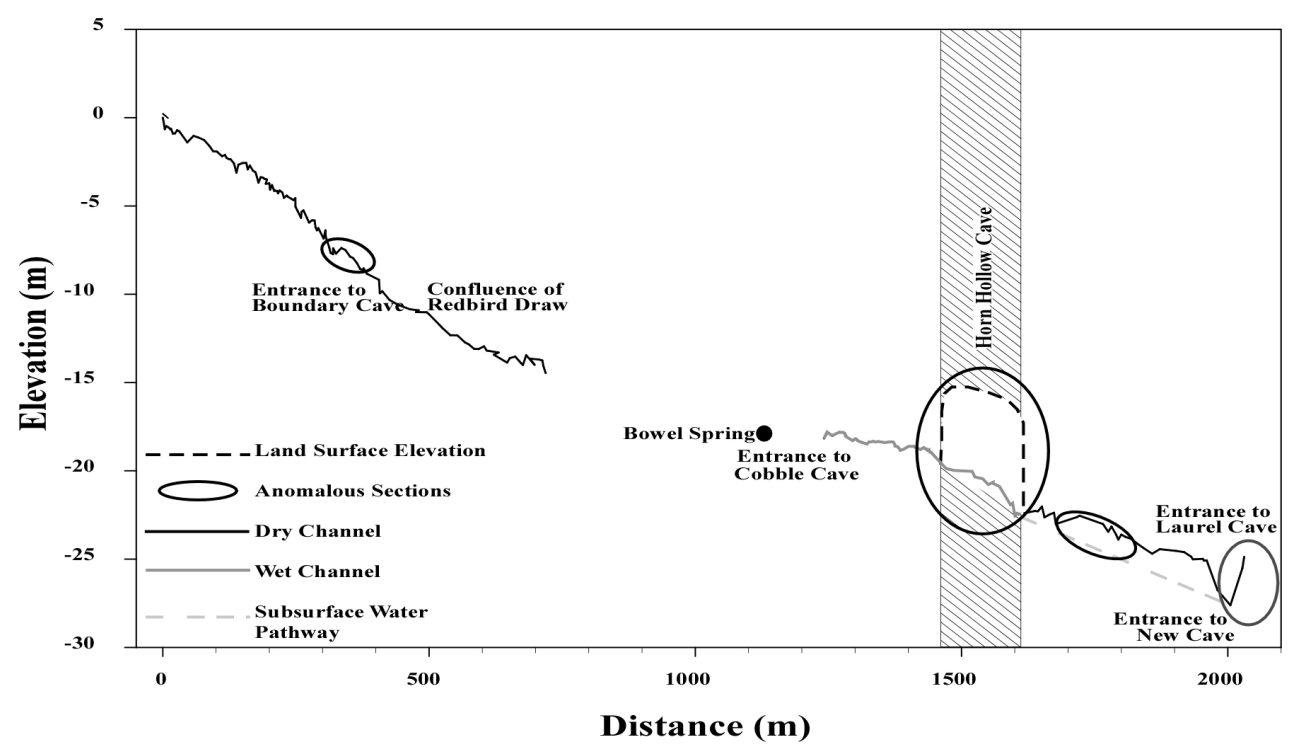

Fig. 4. Locations of anomalous sections along the longitudinal profile of Horn Hollow Creek.

the blind valley wall near the confluence with Cave Branch is a well-defined and relatively large overflow route that clearly can handle significant flows.

The flow paths at the downstream end of the system are more complex than in the rest of the valley. Dye traces have demonstrated that base flows are routed through New Cave, which has a small entrance in a depression at the blind valley wall. The flow path is not traversable, but the water emerges from a spring at the lower end of $\mathrm{H}_{2} \mathrm{O}$ Cave very near the confluence with Cave Branch. During successively higher discharges water is routed first through $\mathrm{H}_{2} \mathrm{O}$ Cave and then through Laurel Cave, which also have entrances in the blind valley wall depression.

The timing of karst formation in CCSRP is not wellconstrained by quantitative dating. However, the general geologic setting is similar to the Mammoth Cave karst to the west and the adjacent Cumberland Plateau karst. Granger et al. (2001) and Anthony and Granger (2004) demonstrated the role of the glacially-influenced development of Teays and Ohio River drainages during the Pleistocene on karst development in those systems. The CCSRP karst was likely formed by related processes during the Pleistocene (Engel \& Engel, 2009). Accordingly, the karst development in CCSRP would have occurred as base-level changes caused by the evolution of the Ohio River drainage raised and lowered water tables in the region. As the water tables adjusted surface valleys, and the associated fluviokarst, would have incised or aggraded.

The upstream ephemeral end of Horn Hollow Creek dissects the siliciclastic units that overlie the Mississippian carbonates. There are a number of smaller draws cut into the valley along either side 
of Horn Hollow. However, the only well-developed tributary valley is Redbird Draw (Fig. 3). Horn Hollow Creek is routed through alternating surface reaches and sub-surface cave reaches several times as it moves down gradient through the system. The head waters are located in Level 4, the uppermost cave level designated by Jacoby et al. (2011b). Coinciding with Cave Levels 4 and 3 within the valley, a dry surface channel overlies the cave stream. The presence of a defined dry channel indicates that the stream once dominated the surface and has since been rerouted to the subsurface. In other sections of the valley, no well-defined surface channel is present, indicating subsurface flow has been dominant in these reaches for extended periods of time. Lying 14 meters below Horn Hollow Creek and within Cave Level 1, Cave Branch serves as base level and the driving force for active downcutting within Horn Hollow Valley.

\section{METHODOLOGY}

Survey data were collected using a Trimble GeoExplorerXT (dGPS), a Nikon Pulse Laser 333 Station (NPLS), and a Laser Atlanta Advantage C1 Laser Range Finder with a Dual Encoding Tripod. Surveys along the thalweg of the stream channel were performed with the NPLS. In many cases, water was not present within the valley, so geomorphic indicators, such as sediment distribution and low points within the streambed, were used to approximate thalweg location. Along the course of the valley, the dGPS was used to record the coordinates of the survey base stations (which were subsequently differentially corrected) and various karst features, which were used to georeference the survey data.

Along the course of Horn Hollow Creek, the stream water enters and exits a number of caves. One of the larger caves is Horn Hollow Cave (HHC). HHC was surveyed using the LRF; a Suunto Tandem surveying compass and a measuring tape were also used as a backup and to ensure accuracy of the survey. No surficial stream channel exists in the reach drained by HHC. Thus, the HHC survey serves to connect the upstream and downstream surface stream profile surveys.

In conjunction with the longitudinal profile, crosssectional profiles were surveyed at locations where channel morphology and sediment distribution appeared to have unique characteristics setting it apart from upstream characteristics. Cross-section were surveyed in channel sections that were riffles. Because some channel segments receive infrequent surface flows due to subsurface piracy channel morphology and bedforms were poorly expressed. In these segments the author's best judgment was used to identify riffle-like areas with caution to avoid any reaches that showed pool-like morphologies. Additionally, the observations used to choose cross-sectional locations included changes in channel morphology, distinct differences in sediment distribution of the bed material, and proximity to known karst features and tributaries. At crosssections where sediment was available, pebble counts (Wolman, 1954) were performed in an area bracketed from 1 meter upstream to 1 meter downstream of the cross-section. Each count consisted of 100 samples, with the exception of cross-section number one, because of the large amount of small particles at that location. Most of the sediment particles were observed to be carbonates with the remaining fraction consisting of siliciclastic rocks, presumably transported from the upland areas of the watershed. The sediment was measured along the intermediate axis using an Albert Scientific Gravelometer.

Potential for sediment movement was examined using the critical shear stress $\left(\tau_{c}\right)$, which represents the tractive force at which particle entrainment begins to occur. Mathematically, $\tau_{\mathrm{c}}$ is expressed as

$$
\tau_{\mathrm{c}}=\Theta_{\mathrm{ec}}\left(\gamma_{\mathrm{s}}{ }^{*} \gamma\right) d
$$

where $\Theta_{e c}$ is the critical dimensionless shear stress, $\gamma_{\mathrm{s}}$ is the weight density of sediment in $\mathrm{N} \mathrm{m}^{-3}, \gamma$ is the weight density of water in $\mathrm{N} \mathrm{m}^{-3}$, and $d$ is the particle diameter in $\mathrm{m}$. Within the Horn Hollow karst system, because of the large amount of water necessary to cause flow along the stream surface, any amount of flow through the valley would be turbulent (i.e., $\Theta_{\mathrm{ec}}=0.044$ ). As most common sediments have a weight density of $26,000 \mathrm{~N} \mathrm{~m}^{-3}$ and water has a weight density of $9,800 \mathrm{~N} \mathrm{~m}^{-3}$, the $\tau_{\mathrm{c}}$ equation may be rewritten as

$$
\tau_{\mathrm{c}}=0.044(26,000-9,800) \mathrm{d}=713 \mathrm{~d}
$$

resulting in units of $\mathrm{N} \mathrm{m}^{-2}$.

Sediment data gathered at the cross-sections were used to calculate critical shear stress values for the $d_{50}$ and $d_{85}$ particles. The $d_{50}$ and $d_{85}$ particle sizes were determined by creating cumulative frequency plots for each pebble-count and determining the grainsize that coincided with the $50^{\text {th }}$ and $85^{\text {th }}$ percentile, respectively. The $d_{50}$ particle represents the median size of the sediment substrate and a lower bracket for estimating sediment mobility. The $\mathrm{d}_{85}$ particle represents an upper threshold for estimating armor destabilization and wholesale substrate mobility (Parker \& Klingeman, 1982; Nino et al., 2003).

Calculations for basal shear stress $\left(\tau_{b}\right)$ for the Horn Hollow system followed earlier work by Dogwiler \& Wicks (2004), employing the equation:

$$
\tau_{\mathrm{b}}=\gamma_{\mathrm{w}} h S_{\mathrm{c}}
$$

where $h$ is water depth in $\mathrm{m}, \gamma_{\mathrm{w}}$ is the specific weight of the fluid $\left(9,800 \mathrm{~N} \mathrm{~m}^{-3}\right)$, and $S_{\mathrm{c}}$ is the channel slope in $\mathrm{m} / \mathrm{m}$ (i.e. dimensionless). The threshold for entrainment $\left(\tau_{\mathrm{b}} / \tau_{\mathrm{c}}>1\right)$ coupled with the calculated $\tau_{c}$ values were used to determine the water depth required to entrain the $d_{50}$ and $d_{85}$ particles at each cross-section.

\section{RESULTS}

\section{Longitudinal Profile}

The longitudinal profile (Figs. 2 and 3) of Horn Hollow Creek was surveyed during baseflow conditions. The starting position for the stream survey was located in the northern portion of Horn Hollow Valley and was 
set as the $0 \mathrm{~m}$ location for both distance and elevation. The survey concluded at the entrance to Laurel Cave. Overall, 2,031 $\mathrm{m}$ of stream were surveyed with a total elevation drop of $24.88 \mathrm{~m}$ in elevation, producing an average gradient of 0.012 .

\section{Upper Segment}

With the exception of high-volume recharge events, the upper segment $(0-720 \mathrm{~m})$ of Horn Hollow Creek is dry. That segment has a stream gradient of 0.020 . The majority of grains are angular to sub-angular. The sizes of the $d_{50}$ and $d_{85}$ grains generally decrease downstream along the profile, following a classical downstream progression (Fig. 3 and Table 1).

Comparison of grain size between $\mathrm{HH} 1$ and $\mathrm{HH} 2$ indicates that the grain-sizes at the two locations are significantly different (Fig. 3). In other stretches from HH3 to HH5, the channel consisted of bare bedrock surface riddled with dissolved pathways and in some areas karren features are present. From HH3 through HH5, the valley has a V-shaped crosssection, indicative of rapid downcutting. Just beyond $\mathrm{HH} 5$, the channel elevation rises $0.33 \mathrm{~m}$ and there is a transition back to a alluvial channel.

Boundary Cave, a pit cave, is the first identified karst feature located within the channel and marks the position of HH6 (362 m). The pit is located along the downstream right edge of the channel. Surface waters pirated into Boundary Cave are transported downgradient along a subsurface level. As opposed to the previous three cross-sections, abundant sediment is present at HH6. The more active portion of the surface channel is approximately $2 \mathrm{~m}$ wide and consists of sub-angular, poorly-sorted gravel and very little vegetation; the less active portion of the channel is approximately $3 \mathrm{~m}$ wide and has noticeably more vegetation. The presence of the pit cave does not mark the beginning or end of any apparent stream profile anomalies, but is located almost precisely in the middle of an upstream anomaly and a downstream anomaly (Fig. 3). The $d_{50}$ and $d_{85}$ particles, comparable in size to those at $\mathrm{HH} 1$, are an exception to the natural progression within the upper segment (Fig. 3 and Table $1)$. While the $d_{85}$ is rather large, shear stress analyses indicate that bankfull $\tau_{\mathrm{b}}$ stresses overcome the critical shear stress associated with the $\mathrm{d}_{85}$ particle; hence, the substrate is mobile during bankfull conditions.

From cross-sections HH8 to HH11, the channel has a defined floodplain, separating the channel from the steep valley walls, and more available sediment within the channel (Fig. 3 and 4). At cross-section HH8 (434 m), the standard deviation is $1.5 \phi$, which classifies the sediment as poorly sorted (Folk, 1974). Sediment is observed within the channel until HH10 (502 m), which consists entirely of bedrock and contains dissolution features similar to those found at HH5. The confluence of Redbird Draw, a dry tributary, is just upstream of this HH10. Although sediment would be delivered to the channel through this tributary, the force of the water may be too great to allow much, if any, sediment to be deposited here. Cross-section HH11 is located near the end of the upper surveyed

Table 1. Sediment statistics for cross-sections of HHC.

\begin{tabular}{|c|c|c|c|c|c|c|c|c|c|}
\hline \multirow{2}{*}{$\begin{array}{c}\text { Cross } \\
\text { Section }\end{array}$} & \multirow{2}{*}{$\begin{array}{c}\text { Sample } \\
\text { Size }\end{array}$} & \multirow{2}{*}{$\begin{array}{l}\text { Bedrock } \\
\text { Samples }\end{array}$} & Median & 25 Percentile & 75 Percentile & $d_{50}$ & $\mathbf{d}_{85}$ & $\tau_{\mathrm{c} 50}$ & $\tau_{\mathrm{c85}}$ \\
\hline & & & (m) & $(\mathrm{m})$ & (m) & (m) & $(\mathrm{m})$ & $\left(\mathbf{N} \mathbf{m}^{-2}\right)$ & $\left(\mathrm{N} \mathrm{m}^{-2}\right)$ \\
\hline 1 & 65 & 0 & 0.090 & 0.032 & 0.18 & 0.07 & 0.21 & 46.35 & 149.73 \\
\hline 2 & 98 & 2 & 0.045 & 0.032 & 0.090 & 0.04 & 0.12 & 25.67 & 85.56 \\
\hline 3 & $\mathrm{NA}^{*}$ & $\ldots$ & & & & $\ldots$ & $\ldots$ & $\ldots$ & $\ldots$ \\
\hline 4 & $\mathrm{NA}^{*}$ & $\ldots$ & & & & $\ldots$ & $\ldots$ & $\ldots$ & $\ldots$ \\
\hline 5 & $\mathrm{NA}^{*}$ & $\ldots$ & & & & $\ldots$ & $\ldots$ & $\ldots$ & $\ldots$ \\
\hline 6 & 100 & 0 & 0.022 & 0.011 & 0.032 & 0.05 & 0.20 & 37.79 & 142.60 \\
\hline 7 & $\mathrm{NA}^{*}$ & $\ldots$ & & & & $\ldots$ & $\ldots$ & $\ldots$ & $\ldots$ \\
\hline 8 & 100 & 0 & 0.064 & 0.016 & 0.180 & 0.02 & 0.05 & 13.55 & 35.65 \\
\hline 9 & 100 & 0 & 0.032 & 0.014 & 0.064 & 0.03 & 0.08 & 18.54 & 58.47 \\
\hline 10 & $\mathrm{NA}^{*}$ & $\ldots$ & & & & $\ldots$ & $\ldots$ & $\ldots$ & $\ldots$ \\
\hline 11 & 100 & 0 & 0.011 & 0.008 & 0.032 & 0.01 & 0.04 & 7.84 & 25.67 \\
\hline 12 & 100 & 0 & 0.032 & 0.023 & 0.045 & 0.03 & 0.05 & 20.68 & 35.65 \\
\hline 13 & 93 & 7 & 0.016 & 0.057 & 0.023 & 0.01 & 0.03 & 8.56 & 18.54 \\
\hline 14 & 99 & 1 & 0.008 & 0.016 & 0.016 & 0.01 & 0.02 & 4.99 & 10.70 \\
\hline 15 & $\mathrm{NA}^{*}$ & $\ldots$ & & & & $\ldots$ & $\ldots$ & $\ldots$ & $\ldots$ \\
\hline 16 & $\mathrm{NA}^{*}$ & $\ldots$ & & & & $\ldots$ & $\ldots$ & $\ldots$ & $\ldots$ \\
\hline 17 & 100 & 0 & 0.045 & 0.016 & 0.090 & 0.04 & 0.16 & 27.09 & 114.08 \\
\hline 18 & $\mathrm{NA}^{*}$ & $\ldots$ & & & & $\ldots$ & $\ldots$ & $\ldots$ & $\ldots$ \\
\hline 19 & 100 & 0 & 0.090 & 0.016 & 0.362 & 0.07 & 0.30 & 51.34 & 213.90 \\
\hline 20 & 100 & 0 & 0.016 & 0.008 & 0.0450 & 0.01 & 0.04 & 9.27 & 28.52 \\
\hline 21 & $\mathrm{NA}^{*}$ & $\ldots$ & & & & $\ldots$ & $\ldots$ & $\ldots$ & $\ldots$ \\
\hline 22 & 100 & 0 & 0.045 & 0.027 & 0.090 & 0.04 & 0.09 & 28.52 & 65.60 \\
\hline
\end{tabular}

* NA indicates that the bed was composed of bedrock 
segment. The channel is very narrow, measuring only $2 \mathrm{~m}$ across. The $\mathrm{d}_{50}$ and $\mathrm{d}_{85}$ and the corresponding shear stress values, are less than the values at HH9 (Fig. 3 and Table 1).

Between the upper segment and the middle segment, the stream channel was not surveyed for two primary reasons: (1) the presence of impounded water behind a large beaver dam midway through the valley and (2) dense vegetation. The distance and elevation of the gap was accounted for by determining the stream length from a topographic map of the area and using the dGPS data to verify distances and elevation.

\section{Middle Segment}

The middle segment $(1,240 \mathrm{~m}-1,450 \mathrm{~m})$ of the longitudinal profile originates with the emergence of water flowing from Cobble Cave and ends at the upstream entrance of HHC. The gradient of the middle segment is 0.005 . Within the middle segment grainsizes decrease along the course of the profile, but the grain-sizes in the segment are larger than those observed upstream at HH11 (Fig. 3 and Table 1). Without sediment data and profile information from the section between the upper and middle segments, it is difficult to determine what the cause may be for the increase in grain-size.

Downstream of Cobble Cave, at cross-section HH12 $(1,259 \mathrm{~m})$, the channel is $8 \mathrm{~m}$ wide, lacks vegetation in the main channel, has a developed floodplain, and contains well-sorted sediments. At HH13 (1,302 m), the downstream right side of the channel has a steeply sloping, nearly vertical, bedrock wall. A portion of the water within the channel flows into anastomotic pathways cut into the rock wall, presumably by dissolution processes. The sediments at HH13 are smaller than at cross-section HH12. A steep slope, approximately $1.5 \mathrm{~m}$ in height composed of alluvium, leads to the small floodplain along the bank. Beyond the plain, steep valley walls, composed of bedrock, are present. Further downstream, nearing HHC, the bedrock wall does not stay in contact with the stream channel. The channel progressively opens up nearer to HHC. Breakdown materials are present outside of the upstream entrance to HHC. The stream is pirated to the subsurface near the cave entrance.

The middle segment does not contain readily apparent anomalies with respect to the shape of the longitudinal profile or the sediment distribution (Fig. 4). However, based on the geomorphology of this segment, an interpretation of its history can be made. First, in contrast to the upper segment, some of the valley walls in this segment are nearly vertical. Downcutting would have to be extremely rapid to incise the valley in this manner, and similar evidence of rapid incision would be expected upstream. Second, the middle segment is bounded by two active cave passages, $\mathrm{CC}$ and $\mathrm{HHC}$. It is highly plausible that these two caves, which are close in elevation and distance, were once connected. The vertical walls present along the valley between these two passages can be interpreted as walls of an ancestral passage whose roof has collapsed. No large materials resembling cavern breakdown are present within this segment; however, the deposition of alluvium within the channel indicates an extended period of time has likely passed since the passage was intact. Within this extended time frame, much of the breakdown material may have been broken down by mechanical and chemical weathering. The shear stress analyses reveal that Horn Hollow Creek is capable of moving at least the $d_{85}$ particles at bankfull conditions, which is consistent with the results of Dogwiler and Wicks (2004) that indicates that this system is capable of transporting the $\mathrm{d}_{85}$ materials on a frequent basis. The high frequency entrainment would provide for transport of breakdown material downstream and would provide a mechanism for mechanical weathering of the larger particles into smaller fragments.

\section{Horn Hollow Cave}

Horn Hollow Cave $(1,450-1,607 \mathrm{~m})$ is an epiphreatic passage, with water flowing through it. The extent of breakdown material within the cave is limited to the upstream and downstream entrances of the cave passage. The cave has sediment deposits throughout the passage. The most notable characteristic of the profile through HHC is the steep drop in elevation from the upstream entrance to the downstream entrance of $\mathrm{HHC}$, resulting in a gradient of 0.023 , which is similar to the upper segment. The survey data extend through the active passage, as opposed to staying on the land surface and going over the cave passage. Had the land surface, where no stream channel exists, been incorporated into the survey, a very apparent anomaly would be present in the profile (Fig. 4). The lack of a surface stream channel and the surface topography at HHC further supports the hypothesis presented above that HHC is a remnant of a longer subterranean flow path that formerly existed in the middle segment of the valley.

\section{Lower Segment}

The lower section $(1,607-2,031 \mathrm{~m})$, beginning at the downstream entrance of $\mathrm{HHC}$ and extending to the upstream entrance to Laurel Cave, has a gradient of 0.006 . The gradient is similar to the gradient between $\mathrm{CC}$ and HHC (0.005) and is less than the combined middle segment and HHC gradient (0.01). Immediately outside of $\mathrm{HHC}$, the water exits the cave, pools, and enters a swallet. No predictable decrease of grain-size is present in this segment; $d_{50}$ and $d_{85}$ grain-sizes increase and decrease along the segment (Fig. 3). The sediment particles, most of which appears to be breakdown from $\mathrm{HHC}$, are notably larger than observed in the upstream and middle segments (Fig. 3).

As the channel meanders downstream of HH17, bare bedrock is exposed along the channel floor. Progressing downstream, bedrock is exposed along the walls of the channel at HH18. In some areas, the rocks resemble the overhanging features present at $\mathrm{HH} 17$, and in other areas, the rocks create a near vertical wall. Approaching cross-section HH19 (1,812 m), the channel widens ( $14 \mathrm{~m}$ wide) and has a welldeveloped floodplain between the valley walls, but has no bedrock walls immediately next to the stream. The channel morphology in this reach is similar to that 
of the middle segment with broad, flat, alluvial banks ( $1.5 \mathrm{~m}$ in height). The sediments in this location are large, angular, heavily imbedded and poorly sorted, forming a nearly linear relationship on a cumulative frequency plot. Much of this material closely resembles the sediment present at $\mathrm{HH} 17$, which indicates that these materials may have been transported to this location and/or resulted by means of cave collapse at or very near this section. The vertical bedrock walls present between HHC leading up to $\mathrm{HH} 19$ are indicative of cave passage collapse. At $\mathrm{HH} 20$, the sediment in the channel is heavily embedded and moderately sorted, with a smaller percentage of large materials than are found at HH17 and HH19. HH21 (1,931 m) had a very small amount of sediment present (sand and smaller), which was insufficient for performing a pebble count. The entrance to $\mathrm{H}_{2} \mathrm{O}$ Cave is located along the edge of HH22. Sediments are moderately sorted, with the larger percentage being between $0.0226-0.0900 \mathrm{~m}$. The steep drop located at 2,005 $\mathrm{m}$ is the entrance to New Cave, and Laurel Cave is the last point on the profile $(2,031 \mathrm{~m})$. The drop into New Cave may be the beginning of a new knick point in the stream and may mark the beginning of another anomalous bump in the profile. Had the overland pass of Laurel Cave been surveyed, an arch similar to that over HHC would occur in the profile (Fig. 4).

\section{DISCUSSION}

At first glance, the longitudinal profile (Fig. 3) of Horn Hollow Creek resembles the concave-up shape often associated with streams at, or near, equilibrium (Fig. 1). In reality, the stream does not assume a smooth concaveup profile; instead, numerous 'bumps', or irregularities, are present along the entire length of the profile. In both karst and non-karst fluvial settings, these bumps can often be attributed to pool-riffle sequences (Mackin, 1948). The longitudinal profile of Horn Hollow Creek resembles this 'bumpy' description (Fig. 3 and 4). However, numerous bumps along the profile are not attributed to pool-riffle sequences. Within a fluviokarst setting, the bumps can also be related to water being re-routed beneath the surface (George, 1989). Along the course of Horn Hollow Creek, four recognizable anomalies have been identified (Fig. 4). They are located near Boundary Cave (HH6), Horn Hollow Cave, between HHC and New Cave (near HH18), and at the entrance to NC. Another smaller anomaly is associated with Redbird Draw, which is tributary to Horn Hollow Creek (Figs. 3 and 4). Another possible explanation for these profile bumps is that they represent localized variations in the bedrock's resistance to weathering. Yet, the association of the profile bumps with sinking points within the stream at three of the four locations suggests that they are not simply caused by variations in bedrock weathering.

The grain-size distribution along the profile provides some indication of karst feature locations. Within the upper segment, Boundary Cave (HH6) was the only cave encountered within the stream channel. The $d_{85}$ material is larger at HH6 $(0.200 \mathrm{~m})$ than the sections immediately before and after (HH5 = bedrock and $\mathrm{HH} 8=0.050 \mathrm{~m}$ ), and slightly smaller than that present at HH1 $(0.210 \mathrm{~m})$. These data contradict the classical stream power dynamics concept that sediment size decreases downstream. During periods of high-flow, water flows into the pit, carrying part of the suspended and bed-loads with it. As the water flows into the pit, the surface stream loses some capacity and competence, resulting in larger particles dropping out of suspension and a decrease in bedload size. Therefore, these materials appear to be present because of the hydraulics of the section, as opposed to collapse of cave passage.

A similar, but smaller, localized increase in grainsize was observed at the confluence of Horn Hollow Creek and Redbird Draw. In this case, the increase in grain-size is likely due to the delivery of coarse sediment to Horn Hollow Creek by Redbird Draw. There are other smaller draws formed along the valley walls of Horn Hollow Creek. It is reasonable to assume that these draws also funnel coarse sediments into Horn Hollow Creek, but they do not strongly influence the downstream grain-size trend.

The upper segment most commonly exhibits a V-shaped channel and lacks the near vertical channel walls present in the middle and lower segments. Additionally, no large materials indicative of cave breakdown are present. The absence of these materials does not make it impossible for this segment to have contained ancestral passages, but rather the lack of vertical rock walls that are exposed in conjunction with the absence of large, breakdown-like materials indicate natural downcutting rather than cave collapse as a mechanism for valley development.

Within the middle segment, the grain-size distribution at the first cross-section (HH12) did not reflect the large particle sizes present at HH6. However, there was an increase in grain-size from that observed at HH11. At $\mathrm{HH} 13$ and $\mathrm{HH} 14$, the grain-sizes were and a decrease at the cross-sections within the middle segment. At HH13, a nearly vertical bedrock wall lies immediately adjacent to the stream and contains anastomotic features at its base, which a portion of the stream flows through. Beyond the banks of the channel, bedrock exposures are present along the valley walls.

There is no apparent evidence within the longitudinal profile or grain size analyses to indicate a karst feature in the middle segment. However, based on observations of the geomorphology, the vertical rock exposures along the valley and channel do not reflect a natural downcutting; instead, they appear to be the result of cavern collapse, suggesting the steep valley walls are remnants of an ancestral cave passage. The lack of apparent breakdown material suggests that the collapse of the former cave passage is sufficiently long ago that mechanical and chemical weathering has had sufficient time to remove the material.

HHC separates the middle and lower segments of the stream profile. During large floods backflooding occurs upstream of HHC because there is no surface overflow route. The decrease in sediment sizes at HH13 and HH14 may be due to backflooding effects that prohibit larger particles from moving downgradient as the floodwaters are encountered. The downstream entrance of HHC 
marks the beginning of the lower segment. Immediately downstream of HHC, Horn Hollow Creek enters a swallet. The longitudinal profile at the end of HHC displays the steep drop out of the cave into the swallet. The grainsizes at $\mathrm{HH} 17\left(\mathrm{~d}_{85}=0.160 \mathrm{~m}\right)$ and $\mathrm{HH} 19\left(\mathrm{~d}_{85}=0.300 \mathrm{~m}\right)$ resemble a magnitude of grain-sizes similar to those of HH1 $\left(\mathrm{d}_{85}=0.210 \mathrm{~m}\right)$ and HH6 $\left(\mathrm{d}_{85}=0.200 \mathrm{~m}\right)$. Since sediment is expected to have a general decreasing trend downstream, the data at $\mathrm{HH} 17$ and $\mathrm{HH} 19$ indicate that other processes are at work within that reach. The channel in this area is predominantly lined by bedrock walls, and large materials on the surface of the channel appear to be a result of collapse, not a result of transport, as they are heavily embedded, very angular, and often exceed a meter in length (on the $b$ axis). Also, some material immediately outside of $\mathrm{HHC}$ sits at angles on the ground or against the outer walls of the cave that suggest recent collapse. These geomorphic features, grain-size, channel morphology, and vicinity to $\mathrm{HHC}$, indicate that the channel between $\mathrm{HHC}$ and $\mathrm{HH} 19$, and possibly beyond, is likely ancestral cave passage. Downstream of $\mathrm{HH} 22$, the entrances to New Cave, Laurel Cave, and $\mathrm{H}_{2} \mathrm{O}$ Cave are in a large basin that acts like a pool during large floods. Because of its pool-like nature, grain-sizes were not collected in this area. Most backflooding within the lower segment of the stream profile would be contained downstream of $\mathrm{HH} 22$.

The longitudinal survey and sediment data reveal anomalous reaches coinciding with present or relict karst features that were identified. Primarily based on geomorphic observations of valley shape, the processes forming these reaches was interpreted as either a result of natural downcutting or cave collapse. The formational mechanism for the upper reaches of Horn Hollow Creek is interpreted as natural downcutting, while portions of the middle and lower segments are interpreted as regions of cave collapse.

\section{CONCLUSIONS}

The longitudinal profile of Horn Hollow creek revealed anomalous concave-down features that help indicate the presence of karst features, past or present, along the course of the stream channel. These downward concavities are present at or near Boundary Cave, Horn Hollow Cave, between HHC and New Cave, and at NC. The approximate location of karst features (e.g. cave passages) were also indicated by irregularities in sediment deposition, specifically an increase in grain-size when compared to cross-sections in close proximity upstream. These increases were present at the entrance to Boundary Cave, the downstream entrance of Cobble Cave, the downstream entrance of Horn Hollow Cave, and near the entrance to New Cave. The sediment analysis alone does not suggest the presence or absence of ancestral cave passage, but may be used in conjunction with geomorphic observations to better support the interpretation of the valley's history. However, the hypothesis that anomalous sections along the length of the profile will have different sediment sizes is supported. In terms of collapse or natural downcutting, the geomorphic expressions of the various segments differ. The upper segment's rock exposures along the v-shaped channel imply natural downcutting, whereas the near vertical rock exposures combined with the vicinity of active cave passages implies that the channel within the middle segment and at least a portion of the lower segment are former cave passages that have collapsed.

The development of the Ohio River during the PlioPleistocene was of critical importance to the cave forming process in this region (Dougherty, 1985; Granger et al., 2001; Anthony \& Granger, 2004). As a tributary to Tygarts Creek, which drains to the Ohio River, Horn Hollow Creek experienced periods of rapid downcutting during the early glacial events of the Plio-Pleistocene (Tierney, 1985). These periods of rapid entrenchment and fluctuations in river flow lowered base level throughout major cave areas within Kentucky (Dougherty, 1985; Granger et al., 2001; Anthony \& Granger, 2004). As a direct result in Horn Hollow, water sought more rapid pathways to the new base level. In many areas along the valley, the water followed fractures in the underlying rock, exposing them to increased dissolution, resulting in the formation of numerous pit caves. The water was also able to cut rapidly through the surface channel and into the underlying carbonates. In some cases, the water may have cut down into phreatic passages, exposing them to the surface and possibly cutting through their roofs in the process. These events would have drastically altered the morphology of Horn Hollow Valley, changing it into something similar to what is present today.

\section{ACKNOWLEDGMENTS}

The authors would like to thank three anonymous reviewers for their assessment and feedback on the paper. Their insight has very useful and much appreciated.

\section{REFERENCES}

Aley T., 1965 - Corrasional cave passage enlargement. Cave Notes, 7 (1): 2-4.

Angel J.C. \& Peterson E.W., 2015 - Nitrates in karst systems: comparing impacted systems to a relatively unimpacted system. Journal of Geography and Geology, 7 (1): 65-76. http://dx.doi.org/10.5539/jgg.v7n1p65

Anthony D.M. \& Granger D.E., 2004 - A Late Tertiary origin for multilevel caves along the western escarpment of the Cumberland Plateau, Tennessee and Kentucky, established by cosmogenic ${ }^{26} \mathrm{Al}$ and ${ }^{10} \mathrm{Be}$. Journal of Cave and Karst Studies, 66 (2): 46-55.

Baker V.R. \& Ritter D.F., 1975 - Competence of rivers to transport coarse bedload material. Geological Society of America Bulletin, 86 (7): 975-978. http://dx.doi.org/ 10.1130/0016-7606(1975)86<975:CORTTC>2.0.CO;2

Bosch R.F. \& White W.B., 2004 - Lithofacies and transport of clastic sediments in karstic aquifers. In: Sasowsky I. \& Mylroie J.E. (Eds.), Studies of cave sediments: Physical and chemical records of paleoclimate. New York, NY: Springer: 1-22.

http://dx.doi.org/10.1007/978-1-4419-9118-8 1

Dogwiler T. \& Wicks C.M., 2004 - Sediment entrainment and transport in fluviokarst systems. Journal of Hydrology, 295: 163-172.

http://dx.doi.org/10.1016/j.jhydrol.2004.03.002 
Dougherty H.P., 1985 - Caves and karst of Kentucky. Kentucky Geological Survey, Special Publication, Lexington, KY, 196 p.

Engel A.S. \& Engel S.A., 2009 - A field guide for the karst of Carter Caves Stat Resort Park and the surrounding area, northeastern Kentucky. In: Engel A.S. \& Engel S.A. (Eds.), Field guide to cave and karst lands of the United States. Karst Waters Institute Special Publication, 15: 154-171.

Folk R.L., 1974 - Petrology of sedimentary rocks. Hemphill, Austin, 182 p.

George A.I., 1989 - Caves and drainage north of the Green River. In: White W.B. \& White E.L. (Eds.), Karst hydrology: Concepts from the Mammoth Cave area. New York: Van Nostrand Reinhold: 189-222. http://dx.doi.org/10.1007/978-1-4615-7317-3_8

Gillieson D.S., 1996 - Caves: Processes, development, and management. Blackwell Publishers, Oxford, 324 p. http://dx.doi.org/10.1002/9781444313680

Granger D.E., Fabel D. \& Palmer A.N., 2001 - Pliocene-Pleistocene incision of the Green River, Kentucky, determined from radioactive decay of cosmogenic ${ }^{26} \mathrm{Al}$ and ${ }^{10} \mathrm{Be}$ in Mammoth Cave sediments. Geological Society of America Bulletin, 113 (7): 825-836. http://dx.doi.org/ 10.1130/0016-7606(2001)113<0825:PPIOTG >2.0.CO;2

Herman E., Toran L. \& White W.B., 2012 - Clastic sediment transport and storage in fluviokarst aquifers: an essential component of karst hydrogeology. Carbonates and Evaporites, 27 (3-4): 211-241. http://dx.doi.org/10.1007/s13146-012-0112-7

Jacoby B., Peterson E.W., Kostelnick J.C. \& Dogwiler T., 2013 - Approaching cave level identification with GIS: A case study of Carter Caves. International Scholarly Research Notices Geology, 2013 (160397): 7. http://dx.doi.org/10.1155/2013/160397

Jacoby B.S., Peterson E.W. \& Dogwiler T., $2011 \mathrm{a}$ Identifying the stream erosion potential of cave levels in Carter Cave State Resort Park, Kentucky, USA. Journal of Geographic Information Systems, 3 (4): 323-333. http://dx.doi.org/10.4236/igis.2011.34030

Jacoby B.S., Peterson E.W., Dogwiler T. \& Kostelnick J.C., 2011b - Estimating the timing of cave level development with GIS. Speleogenesis and Evolution of Karst Aquifers, 11: 52-61.

Jennings J.N., 1985 - Karst geomorphology. Basil Blackwell Inc., New York, 293 p.

Leopold L.B., Wolman M.G. \& Miller J.P., 1964 - Fluvial processes in geomorphology. W.H. Freeman and Company, San Francisco, 522 p.

Lorang M.S. \& Hauer F.R., 2003 - Flow competence and streambed stability: An evaluation of technique and application. Journal of North American Benthological Society, 22 (4): 475-491.

http://dx.doi.org/10.2307/1468347

Mackin J.H., 1948 - Concept of the graded river. Geological Society of America Bulletin, 59 (5): 463-512. http://dx.doi.org/10.1130/0016-7606(1948)59 [463:COTGR]2.0.CO;2
McGrain P., 1966 - Geology of Carter and Cascade Caves Area. Kentucky Geological Survey, 32 p.

Nino Y., Lopez F. \& Garcia M., 2003 - Threshold for particle entrainment into suspension. Sedimentology, 50: 247-263. http://dx.doi.org/10.1046/j.1365-3091.2003.00551.x

Ochsenbein G.D., 1974, Origin of caves in Carter Caves State Park, Carter County, Kentucky. Unpublished MS thesis, Bowling Green State University, 64 p.

Palmer A.N., 1991 - Origin and morphology of limestone caves. Geological Society of America Bulletin, 103 (1): 1-21. http://dx.doi.org/10.1130/0016-7606(1991)103 $\leq 0001$ :OAMOLC $>2.3 . \mathrm{CO} ; 2$

Parker G. \& Klingeman P.C., 1982 - On why gravel bed streams are paved. Water Resources Research, 18 (5): 1409-1423. http://dx.doi.org/10.1029/WR018i005p01409

Peterson E., Dogwiler T. \& Harlan L., 2011 - Using GIS to identify cave levels and discern the speleogenesis of the Carter Caves karst area, Kentucky. In: Kuniansky E.L. (Ed.), U.S. Geological Survey Karst Interest Group Proceedings, Fayetteville, Arkansas (April 26-29, 2011). Reston, Virginia: United States Geological Survey: 94-103.

Sanders W., 1981 - Limestone denudation. In: Sweeting M.M. (Ed.), Karst geomorphology: Benchmark papers in geology. Stroudsburg, Pennsylvania: Hutchinson Ross Publishing Company: 320-343.

Sklar L.S. \& Dietrich W.E., 2001 - Sediment and rock strength controls on river incision into bedrock. Geology, 29 (12): 1087-1090.

http://dx.doi.org/10.1130/0091-7613(2001)029 $\leq 1087$ :SARSCO $>2.0$. CO;2

Tierney J., 1985 - Caves of northeastern Kentucky (with special emphasis on Carter Caves State Park). In: Dougherty P.H. (Ed.), Caves and karst of Kentucky. Lexington, KY: Kentucky Geological Survey: 78-85.

Van Gundy J.J. \& White W.B., 2009 - Sediment flushing in Mystic Cave, West Virginia, USA, in response to the 1985 Potomac Valley flood. International Journal of Speleology, 38 (2): 103-109. http://dx.doi.org/10.5038/1827-806X.38.2.2

Whipple K.X., Hancock G.S. \& Anderson R.S., 2000 - River incision into bedrock: Mechanics and relative efficacy of plucking, abrasion, and cavitation. Geological Society of America Bulletin, 112 (3): 490-503.

http:/ / dx.doi.org/10.1130/0016-7606(2000)112 <490:RIIBMA>2.0.CO;2

White E.L. \& White W.B., 1968 - Dynamics of sediment transport in limesone caves. The National Speleological Society Bulletin, 30 (4): 115-129.

White W.B., 1988 - Geomorphology and hydrology of karst terrains. Oxford University Press, New York, 464 p.

Wolman M.G., 1954 - A method of sampling coarse riverbed material. Transactions American Geophysical Union, 35 (6): 951-956. http://dx.doi.org/10.1029/TR035i006p00951 